\title{
Early Diagnosis Behavior in Turkish Women with and without a Family History of Cervical Cancer
}

\author{
Cansu Gunaydın ${ }^{1}$ Nuran Gencturk ${ }^{2 *}$
}

\begin{abstract}
Background: This study was planned as comparative and descriptive in order to measure and evaluate the knowledge and attitudes regarding early diagnosis of women with and without a family history of cervical cancer. Materials and Methods: The study sample consisted of the relatives of female patients $(\mathrm{N}=253)$ who were admitted to Istanbul University of Medicine. Women with a family history of cervical cancer formed the case group, while those without family history of cervical cancer constituted the control group. Two distinct data collection tools, a questionnaire and the Miller Behavioral Style Scale (MBSS), were used in order to obtain data for evaluation with SPSS for Windows 20.0 statistics package program. Results: It was found that 61.0\% of the case group with family history of cervical cancer and $19.0 \%$ of the control group without family history of cervical cancer were using early diagnostic methods. Thus the presence of an individual with cervical cancer in the family affected the attitudes towards early diagnosis. It was further found that the level of knowledge on cervical cancer and PAP smear test was higher in the case group, which was more sensitive with regard to being informed about cervical cancer as compared to general society. However, the average MBSS scores were not significantly different compared to the control group. Conclusions: It was noted that, women participating this study knowledgeable, but this did not necessarily transform into better behavior.
\end{abstract}

Keywords: Cervical cancer - human papilloma virus - midwifery - PAP test

Asian Pac J Cancer Prev, 16 (2), 401-406

\section{Introduction}

Cervical cancer is one of the gynecologic cancers that can be early diagnosed easily. However, it has a high mortality when it is not diagnosed at early stage. Prevalence of gynecologic cancers varies from country to country and depends on socioeconomic condition of the country. The most common type of gynecologic cancer in the world is "cervical cancer", originating from the neck of the uterus, is also called as cancer of the neck of the uterus by lay people (Saslow et al., 2002; Bekar, 2008; WHO, 2008; Ertem, 2009). Cervical cancer is the fourth most common cancer in women and the seventh overall, with an estimated 528,000 new cases in 2012. (IARC, 2012; Yildirim et al., 2014).

Since cervical cancers do not manifest finding during early stage, Papanicolaou (PAP) smear test is important in early detection. Pap smear test is a rather sensitive test and it allows detection of precancerous changes in cervical cells, it can prevent development of invasive cancer (Anttila et al., 2004; Kose, 2006). Because of treatability of the cervical cancers at early stage, American cancer society (ACS) suggests Pap smear test and pelvic examination in all women above 21 years of age and in women who are under 21 but have an active sexual life. When annual examinations yield negative PAP smear test three times, it can be dome less frequently with recommendation of the physician (Saslow et al., 2002; Sirovich and Welch, 2004; Ayhan and Basaran, 2006; Kose, 2006; Isik Andsoy et al., 2014; http://www.ztb.gov. tr/saglik-rehberi/smear-takibinde-son-gelismeler/130).

The purpose of screening in the cervical cancer is to detect it at preinvasive stage when the chance of treatment is high and cost of treatment is less compared to invasive stage. In order to allow women use this possibility, it is necessary to educate women about PAP smear test and encourage them to have regular PAP smear test. Midwives, who are involved in health team, are in continuous communication with the patients. Besides, midwives carry ill and healthy individuals' responsibility as well as their own health responsibility due to their educational and supportive roles and the knowledge they have.

The present study was planned as comparative and descriptive manner in order to measure and evaluate the attitudes of women with and without family history of cervical cancer on early diagnosis, attract their attention on PAP smear test and create an awareness in their behaviors about this issue. 


\section{Materials and Methods}

\section{Study design}

This study was planned as comparative and descriptive manner in order to measure and evaluate the knowledge and attitudes of women with and without family history of cervical cancer for early diagnosis.

\section{Setting and sample}

Sampling of the study consisted of 253 women and they included first-degree relatives of women who admitted to IU Istanbul medical faculty, gynecologic section of department of obstetrics and gynecology and IU oncology institute during last five years with the diagnosis of cervical cancer and women with no first-degree relative diagnosed cervical cancer in last five years who admitted to IU istanbul medical faculty, outpatient clinics at department of internal medicine and who accepted to participate in this study. Of these women, 100 who had a first degree relative with cervical cancer in family constituted the case group, while 153 who had no first degree relative with cervical cancer formed the control group.

\section{Ethical consideration}

A written permission was obtained from clinical research ethical committee of IU istanbul medical faculty, from obstetrics and gynecology department, from directorate of IU oncology institute and from associate professor Nuran Gencturk, who adapted Miller behavioral style scale (MBSS) to Turkish society. Besides, purpose of the study was explained and oral and written permissions were obtained from all women who participated the study.

\section{Measurements/Instruments}

Two distinct data collection tools, "Detection of attitudes of women with and without family history of cervical cancer on early diagnosis" Survey form and the Miller behavioral style scale (MBSS), that evaluated the behavioral patterns of the individuals who are at danger/ risk on seeking information were used in order to obtain data.

There are four distinct and fictive dangerous/risky conditions and eight different choices for each condition in Miller behavioral style scale. Four of the eight choices below each dangerous/risky condition imply monitor, while the other four choices imply individuals who are blunter. MBSS consists of total 32 choices of which 16 would be marked by individuals who are monitor and rest 16 choices would be marked by individuals who are blunter. In evaluating MBSS, the choice involving monitor is given (+1) point and the choice involving blunter is given (-1) point. From marked choices, difference between choices that are monitor and blunter is found. Those who attain 0 to 16 points are evaluated as monitor, whereas those who get points below 0 are considered as individuals who are blunter.

\section{Data collection/Procedure}

Data collection took approximately 15 months from June $8^{\text {th }}$ in 2011 to September $7^{\text {th }}$ in 2012. First ethical approval taken from goverment agencies and from the participants. Second the researchers was applied questionnaire and MBSS at IU istanbul medical faculty, gynecologic section of department of obstetrics and gynecology and IU oncology institute and outpatient clinics at department of internal medicine.

Participants who agree to take part in the stuffy were taken into interview rooms and questionnaire and MBSS were filled with face-to-face interview method at 15 minutes.

\section{Data analysis}

Evaluation of the data obtained in this study was done with SPSS for windows 20.0 statistics package program. Average, standard deviation, frequency, ratio values, Chisquare test and Fischer exact-test (when Chi-square was not applicable) were used in analysis of the data.

\section{Results}

Differences of average age, distribution of age, educational status, socio-economic status, health insurance status were not statistically significant in case and control groups (Table 1). When consideration of being at risk for cervical cancer was compared, there was statistically significant difference between the participants in case and control groups $(\mathrm{p}=0.000, \mathrm{p}<0.001)$. This is an expected consequence since individuals in case group had a firstdegree relative with cervical cancer in their family, while those in control group did not (Table 2).

There was a statistically significant difference in being knowledgeable about cervical cancer between case and control groups $(\mathrm{p}=0.000, \mathrm{p}<0.001)$. It is probable that participants who have a first-degree relative with cervical

Table 1. Socio-demographic Characteristics and Comparison of Case and Control Group

\begin{tabular}{|c|c|c|c|c|c|}
\hline \multirow[t]{2}{*}{$\begin{array}{l}\text { Socio-demographic } \\
\text { Characteristics }\end{array}$} & \multicolumn{2}{|c|}{$\begin{array}{l}\text { Case Group } \\
\quad(n=100)\end{array}$} & \multicolumn{2}{|c|}{$\begin{array}{l}\text { Control Group } \\
(n=153)\end{array}$} & \multirow[t]{2}{*}{$\mathrm{p}^{*}$} \\
\hline & $\mathrm{n}$ & $\%$ & $\mathrm{n}$ & $\%$ & \\
\hline Average Age & \multicolumn{2}{|c|}{$38.2 \pm 11.3$} & \multicolumn{2}{|c|}{$37.8 \pm 10.8$} & 0.781 \\
\hline Age $18-28$ & 19 & 19.0 & 32 & 20.9 & 0.362 \\
\hline $29-38$ & 39 & 39.0 & 51 & 33.3 & \\
\hline $39-48$ & 23 & 23.0 & 43 & 28.1 & \\
\hline $49-58$ & 12 & 12.0 & 23 & 15.0 & \\
\hline $59 \leq$ & 7 & 7.0 & 4 & 2.7 & \\
\hline \multicolumn{6}{|l|}{ Educational Status } \\
\hline Illiterate & 4 & 4.0 & 6 & 3.9 & \multirow[t]{5}{*}{0.242} \\
\hline Elementary School & 24 & 24.0 & 44 & 28.8 & \\
\hline Secondary School & 17 & 17.0 & 22 & 14.4 & \\
\hline High School & 22 & 22.0 & 40 & 26.1 & \\
\hline University/Masterdegree & e 33 & 33.0 & 41 & 26.8 & \\
\hline \multicolumn{6}{|l|}{ Occupational Status } \\
\hline Working & 52 & 52.0 & 70 & 45.8 & \multirow[t]{2}{*}{0.331} \\
\hline Not working & 48 & 48.0 & 83 & 54.2 & \\
\hline \multicolumn{6}{|l|}{ Socio-economic Status } \\
\hline Poor & 6 & 6.0 & 16 & 10.5 & \multirow[t]{3}{*}{0.055} \\
\hline Moderate & 52 & 52.0 & 94 & 61.4 & \\
\hline Good & 42 & 42.0 & 43 & 28.1 & \\
\hline \multicolumn{6}{|l|}{ Health Insurance } \\
\hline None & 3 & 3.0 & 6 & 4.0 & \multirow[t]{2}{*}{1.000} \\
\hline Present & 97 & 97.0 & 147 & 96.0 & \\
\hline
\end{tabular}

*Chi-square test/independent sampling test 
Early Diagnosis Behavior in Turkish Women with and without a Family History of Cervical Cancer

Table 2. Cervical Cancer Protection Status in Case and Control Groups

\begin{tabular}{|c|c|c|c|c|c|}
\hline \multirow{2}{*}{$\begin{array}{l}\text { Cervical Cancer } \\
\text { Protection Status }\end{array}$} & \multicolumn{2}{|c|}{ Case Group } & \multicolumn{2}{|c|}{ Control Group } & \multirow[t]{2}{*}{$\mathrm{p}$} \\
\hline & $\mathrm{n}$ & $\%$ & $\mathrm{n}$ & $\%$ & \\
\hline \multicolumn{6}{|c|}{ Considering themselves at risk for cervical cancer (Case Group $n=100$ Control Group $n=153$ Total $N=253$ ) } \\
\hline Yes & 85 & 85.0 & 19 & 12.4 & \multirow[t]{2}{*}{0.000} \\
\hline No & 15 & 15.0 & 134 & 87.6 & \\
\hline \multicolumn{6}{|c|}{ Reasons for considering themselves at risk for cervical cancer (Case Group n=85 Control Group n=19) } \\
\hline Frequent vaginal infection & 5 & 5.9 & 9 & 47.4 & \\
\hline Family history of cervical cancer & 78 & 91.8 & 0 & 0.0 & \\
\hline Having many deliveries & 2 & 2.3 & 3 & 15.8 & \\
\hline Frequent sexual intercourse & 0 & 0.0 & 1 & 5.2 & \\
\hline Unprotected sexual intercourse & 0 & 0.0 & 3 & 15.8 & \\
\hline None responders & 0 & 0.0 & 3 & 15.8 & \\
\hline \multicolumn{6}{|c|}{ Protection from cervical cancer or applying early diagnosis method (Case Group $n=100$ Control Group $n=153$ ) } \\
\hline Yes & 61 & 61.0 & 29 & 19.0 & \multirow[t]{2}{*}{0.000} \\
\hline No & 39 & 39.0 & 124 & 81.0 & \\
\hline \multicolumn{6}{|c|}{ Protection from cervical cancer or applying early diagnosis method (Case Group $n=61$ Control Group n=29 Toplam n=90) } \\
\hline Regular health check up & 23 & 37.7 & 10 & 34.5 & \\
\hline Taking care of genital hygiene & 8 & 13.1 & 0 & 0.0 & \\
\hline Regular PAP Smear Test & 26 & 42.6 & 17 & 58.6 & \\
\hline Using condom during sexual intercourse & 4 & 6.5 & 0 & 0.0 & \\
\hline Not using any early diagnosis method & 9 & 14.7 & 2 & 6.9 & \\
\hline \multicolumn{6}{|l|}{ PAP Smear Test (Case Group $n=100$ Control Group $n=153$ ) } \\
\hline Yes & 83 & 83.0 & 63 & 41.2 & \multirow[t]{2}{*}{0.000} \\
\hline No & 17 & 17.0 & 90 & 58.8 & \\
\hline \multicolumn{6}{|c|}{ Frequency of PAP Smear Test (Case Group $n=83$ Control Group $n=63$ Total $n=146$ ) } \\
\hline Every six months & 4 & 4.8 & 3 & 4.8 & \multirow[t]{4}{*}{0.776} \\
\hline Annually & 38 & 45.8 & 26 & 41.3 & \\
\hline Once in $3-5$ years & 14 & 16.9 & 11 & 17.5 & \\
\hline When physician orders it & 27 & 32.5 & 23 & 36.5 & \\
\hline \multicolumn{6}{|c|}{ Reason for PAP Smear Test (Case Group $n=83$ Control Group $n=63$ Total $n=146$ ) } \\
\hline For regular health check up & 19 & 22.9 & 32 & 50.8 & \\
\hline Because physician orders it & & 15 & 18.1 & 21 & 33.3 \\
\hline Because there is a relative with cervical cancer in the family & & 38 & 45.8 & 0 & 0.0 \\
\hline Because of vaginal discharge. itching. bleeding complaints & & 8 & 9.6 & 7 & 11.1 \\
\hline Because of concern for carcer & & 4 & 4.8 & 5 & 7.9 \\
\hline
\end{tabular}

Table 3. Comparison of Case and Control Groups in Tems of Knowledge Status on Cervical Cancer, PAP Smear Test and Cervical Cancer Vaccine

\begin{tabular}{|c|c|c|c|c|c|}
\hline \multirow{2}{*}{$\begin{array}{l}\text { Knowledge Status Case and Control Groups on Cervical Cancer, } \\
\text { PAP Smear Test and Cervical Cancer Vaccine }\end{array}$} & \multicolumn{2}{|c|}{ Case Group } & \multicolumn{2}{|c|}{ Control Group } & \multirow[t]{2}{*}{$\mathrm{p}^{*}$} \\
\hline & $\mathrm{n}$ & $\%$ & $\mathrm{n}$ & $\%$ & \\
\hline \multicolumn{6}{|l|}{ Knowledge on Cervical Cancer } \\
\hline Present & 67 & 67.0 & 55 & 35.9 & 0.000 \\
\hline None & 33 & 33.0 & 98 & 64.1 & \\
\hline \multicolumn{6}{|l|}{ Knowledge on PAP Smear Test } \\
\hline Present & 76 & 76.0 & 65 & 42.5 & 0.000 \\
\hline None & 24 & 24.0 & 88 & 57.5 & \\
\hline \multicolumn{6}{|l|}{ Knowledge on Cervical Cancer Vaccine } \\
\hline Present & 39 & 39.0 & 56 & 36.6 & 0.700 \\
\hline None & 61 & 61.0 & 97 & 63.4 & \\
\hline
\end{tabular}

*Chi-square test

cancer seek more information about cervical cancer compared to general population (Table 3 ).

Considering that awareness of being at danger/risk for cervical cancer could affect status of being monitor, when average scores of monitor in MBSS that was applied to case group with family history of cervical cancer and control group with no family history of cervical cancer were compared, contrary to our belief, eagerness to seek information was similar in the groups and there was not any statistically significant difference $(\mathrm{p}=0.203, \mathrm{p}>0.05)$ (Table 4).

When average MBSS scores and age $(p=0.949$, $\mathrm{p}=0.721, \mathrm{p}=0.058, \mathrm{p}=0.249, \mathrm{p}=0.350, \mathrm{p}>0.05)$, education $(\mathrm{p}=0.275, \mathrm{p}=0.228, \mathrm{p}=0.225, \mathrm{p}=0.069, \mathrm{p}>0.05)$ and occupational status $(p=0.449, p=0.557, p>0.05)$ were

Table 4. Comparison of Average MBSS Scores in Case and Control Groups

\begin{tabular}{lccccc}
\hline $\begin{array}{l}\text { Comparison of Average } \\
\text { MBSS Scores in Case }\end{array}$ & $\begin{array}{c}\text { Case Group } \\
(\mathrm{n}=100)\end{array}$ & $\begin{array}{c}\text { Control Group } \\
(\mathrm{n}=153)\end{array}$ & $\mathrm{p}$ \\
\cline { 2 - 3 } and Control Groups & $\mathrm{n} \quad \%$ & & $\mathrm{n}$ & \\
\hline Average MBSS Scores & Mean $\pm \mathrm{SS}$ & & Mean $\pm \mathrm{ss}$ & \\
& $3.7 \pm 4.8$ & & $3.5 \pm 4.2$ & 0.203 \\
\hline *Chi-square test & & & &
\end{tabular}


Table 5. Comparison of Average MBSS Scores and Age, Educational and Occupational Status in Case and Control Groups

\begin{tabular}{|c|c|c|c|c|}
\hline \multirow{2}{*}{\multicolumn{2}{|c|}{$\begin{array}{l}\text { Comparison of Average MBSS Scores and Age, Educational } \\
\text { and Occupational Status in Case and Control Groups }\end{array}$}} & \multirow{2}{*}{$\begin{array}{l}\text { Case Group Average } \\
\text { MBSS Scores } \\
\text { Mean } \pm \text { ss } \\
\end{array}$} & \multirow{2}{*}{$\begin{array}{l}\text { Control Group Average } \\
\text { MBSS Scores } \\
\text { Mean } \pm \text { ss }\end{array}$} & \multirow[t]{2}{*}{$\mathrm{p}^{*}$} \\
\hline & & & & \\
\hline Age & $18-28$ & $2.47 \pm 5.03$ & $2.56 \pm 4.58$ & 0.949 \\
\hline & $29-38$ & $4.10 \pm 4.65$ & $3.76 \pm 4.25$ & 0.721 \\
\hline & $39-48$ & $5.48 \pm 4.11$ & $3.37 \pm 4.29$ & 0.058 \\
\hline & $49-58$ & $2.67 \pm 5.68$ & $4.39 \pm 3.24$ & 0.249 \\
\hline & $59 \leq$ & $0.43 \pm 3.82$ & $3.00 \pm 4.76$ & 0.350 \\
\hline \multicolumn{5}{|c|}{ Educational Status } \\
\hline & Illiterate & $1.61 \pm 4.61$ & $2.74 \pm 4.23$ & 0.275 \\
\hline & Elementary (Primary-Junior High) & $3.47 \pm 4.06$ & $1.82 \pm 4.25$ & 0.228 \\
\hline & High School & $1.95 \pm 5.13$ & $3.50 \pm 4.53$ & 0.225 \\
\hline & University/Master degree & $6.70 \pm 3.57$ & $5.24 \pm 3.18$ & 0.069 \\
\hline \multicolumn{5}{|c|}{ Occupational Status } \\
\hline & Working & $5.21 \pm 4.53$ & $4.64 \pm 3.72$ & 0.449 \\
\hline & Not working & $2.02 \pm 4.58$ & $2.49 \pm 4.34$ & 0.557 \\
\hline
\end{tabular}

compared between case and control groups, it was found that both groups were similar in terms of monitor. When case and control groups were compared in regard to average scores for monitor, there was not ant statistically significant. It was found that average MBSS scores were higher in 39-48 $(5.48 \pm 4.11)$ age group of case group and $49-58(4.39 \pm 3.24)$ age group of control group. Taking this in account, it was thought that individuals with family history of cervical cancer had cervical cancer awareness compared to control group and they were in search regarding cervical cancer and early diagnosis (Table 5). As a result, it can be stated that lack of significant difference in MBSS average scores between case and control groups is affected by various factors such as privacy feeling in women, fatalistic approach and concern of facing an unwanted result.

\section{Discussion}

Acıkgoz et al. (2011) reported that $61.2 \%$ of the participants has health insurance. Our study is consistent with this, suggesting that participants with a health insurance can benefit more easily from early diagnostic methods compared to those without a health insurance.

In a study conducted on nurses working at an educational hospital, Ozdemir and Bilgili (2010) examined the knowledge and practices of the nurses about early diagnosis of cervical cancer. The authors found that $31.8 \%$ of the nurses considered themselves at risk for cervical cancer and 22.5 of these reported that they considered themselves at risk because of genetic tendency. This study does not resemble our findings. This is because presence of an individual with cervical cancer in the family leads the participants in case group to consider themselves at higher risk, while absence of an individual with cervical cancer in the family leads the participants in control group to consider themselves at lower risk.

Papanicolaou (PAP) smear test is a simple test used in many countries for screening cervical cancer (Gokaslan and Uyar, 2004). It is reported that there are several health behaviors decreasing the risk for cervical cancer, however no attitude is as effective as having PAP smear test
(Dozier and Lawrence, 2000). It is emphasized that with use of routine PAP smear screening test for last 50 years, rates of invasive cervical cancer decreased in developed countries (Saraiya, 2003; Waxman, 2005). In high risk cases, PAP smear test should be done at every opportunity (Ozan, 2005; Numanoglu, 2010). In our countries, publicbased screenings for cervical cancer are conducted by cancer early diagnosis, screening and education centers (KETEM), that belongs to family health center and public health center. Considering the conditions of our country, target population is women between 30-65 years of age. HPV test or PAP smear test will be performed every five years in target population for screening. Screening should be terminated in 65-year-old women whose last two HPV test or PAP smear test is negative (Isik Andsoy et al., 2014; http://kanser.gov.tr/kanser/kanser-taramalari/886serviks-kanseri-tarama-program\%C4\%B1.html; http:// www.ztb.gov.tr/saglik-rehberi/smear-takibinde-songelismeler/130).

When protection from cervical cancer or practicing early diagnosis is compared between case group and control group, a statistically significant difference was found ( $\mathrm{p}=0.000, \mathrm{p}<0.001$ ) (Table 2). Performing PAPstatus in case group was statistically significant compared to control group, while there was not any statistically significant difference between case and control groups regarding frequency of PAP smear test (Table 2). The reason for this difference in the study is that those in case group has family members with cervical cancer and hence they admit to physician with their own desire. The reason for absence of difference between case and control groups in terms of PAP smear test frequency is that physicians ask performing PAP smear test annually when they visit a gynecologist for various reasons. Here women in control group do not admit a doctor unless they experience a gynecologic problem. In a study conducted by Ozan and Ertem (2011) to measure frequency of cervical cancer screening and level of knowledge, $41.3 \%$ of the women reported that PAP smear test should be done at least once in a lifetime and $50.9 \%$ reported that this test should be done regularly. This study is consistent with our findings in control group. 
Akyuz et al. (2006) conducted a study to investigate PAP smear test status of the women and factors affecting this and they found that there was a significant relation between considering oneself at high risk for cervical cancer and PAP smear test status $(\mathrm{p}<0.001)$. Bilge and Unal (2005) reported that relatives of patients with cancer can experience continuous anger and anxiety because of fear of death regarding their relatives, thought of cancer in themselves and therefore being required to make changes in their lives and accompanying the ill relatives during treatment process. Besides, this study found that protection from cancer could lead to prevent usual behaviors (Bilge and Unal, 2005). Therefore it can be concluded that compared to general population, an individual who considers herself at risk seeks more opportunities for early diagnosis. Case group in this study showed resemblance with literature findings in terms of considering oneself at risk for cervical cancer, protection from cervical cancer or practicing any type of methods for early diagnosis.

Cervical cancer is the type of cancer in which benefit of early diagnosis is best shown and thanks to early diagnosis, chance of treatment is increased to $100 \%$ while mortality due to cervical cancer is decreased $50 \%$. Pathologic changes that originate in epithelium during asymptomatic phase and can not be noticed by naked eye can be easily diagnosed by PAP smear test. It is reported that PAP smear test, used in early diagnosis, is an easily performed, low-cost, harmless test with a high sensitivity and it also decreases treatment burden, morbidity and mortality (Ozdemir and Bilgili, 2010).

There was a statistically significant difference in being knowledgeable about cervical cancer between case and control groups $(\mathrm{p}=0.000, \mathrm{p}<0.001)$ (Table 3$)$. This fact implies that participants with a family history of cervical cancer seem to be more closely concerned about cervical cancer and they tend to investigate cervical cancer and modalities of early diagnosis. Gumus and Cam (2011) analyzed the attitudes of women for cervical cancer and reported that $41,8 \%$ of the randomized women had information about PAP smear test and 20.8\% had their PAP smear test done. Our study is not consistent with Gumus and Cam's study because participants in case group had a higher awareness about cervical cancer and PAP smear test since these women had a family history of cervical cancer. Participants who are knowledgeable and have awareness about cervical cancer also have knowledge on PAP smear test and this explains the statistical difference between case and control groups.

It is demonstrated in many studies that Human Papilloma Virus (HPV) vaccines have protective effect against particularly cervical cancer and warts. HPV vaccines should be administered to girls prior to sexual intercourse age. Presently there are two companies who developed HPV vaccine in our country. The vaccination is routinely suggested in in more than 150 countries (Hacımustafaoglu 2011; Yildirim et al. 2014). Since studies on prevalence and epidemiologic studies are not sufficient, Turkish pediatrics association has no clear suggestion on administration of this vaccine regularly (Hacımustafaoglu, 2011). When knowledge levels on cervical cancer vaccine were compared between case and control group, no statistically significant difference was noted ( $\mathrm{p}=0.700, \mathrm{p}>0.05$ ) (Table 3 ). Reason for this result in our study could be absence of HPV vaccines in routine vaccination calendar and therefore women had not heard of HPV vaccines. In studies conducted about HPV vaccines it was reproted that $60 \%$ to $89 \%$ of the women did not hear about these vaccines (Brabin et al., 2006; Giles and Garland, 2006; Moraros et al., 2006; Dinh et al., 2007; Lenehan et al., 2008; Yildirim et al. 2014). These studies are consistent with our findings.

In conclusion, it was found that level of knowledge on cervical cancer and PAP smear test was higher in case group compared to control group and case group was more sensitive for being informed about cervical cancer compared to general society. It was found that MBSS scores in women with family history of cervical cancer were not significantly different than those with no family history of cervical cancer. It was detected that women participating this study were eager to obtain information on cervical cancer in general. However, it was found that women could not transform this information into behavior due to reasons such as privacy feeling, fatalistic approach and concern about facing an unwanted result. Under the light of these results, it can be recommended that; $i$ ) Conducting this study, which was done in a relatively small region with a small sampling group, in Turkeywide, ii) In our society, where periodic health check up is not a habit, educating and encouraging all women for screenings at certain intervals by midwives. iii) Instructing women regularly by midwives on issues such as cervical cancer, risk factors involving cervical cancer, protection modalities from cervical cancer, PAP smear test, HPV and HPV vaccine, iv) Making PAP smear test a routine part of gynecologic examination in all women.

\section{Acknowledgements}

We would like to thank Emre Onat for assistance in the translation of this article.

\section{References}

Acıkgoz A, Cehreli R, Ellidokuz H (2011). Women's knowledge and attitudes about cancer and early detection methods for their behavior. Dokuz Eylul Univ Fac Medicine Magazine, 25, 145-54.

Akyuz A, Guvenc G, Yavan T, Cetinturk A, Kok G (2006). Situation of women with Pap Tests determination of factors influencing. Gulhane Medical Journal, 48, 25-9.

Anttila A, Ronco G, Clifford G, et al (2004). Cervical cancer screening programmes and policies in 18 European countries. Br J Cancer, 91, 935-41.

Ayhan A, Basaran M (2006). Invasive cervical cancers. In MS Beksac, N Demir, ZS Tuncer, et al (Eds.). Gynecology, Reproductive Endocrinology and Infertility and Gynecologic Oncology, (pp.1364-1367). Ankara: Medical Network.

Bekar M (2008). Benign and malignant tumors of the female genital tract. In A Sirin, O Kavlak (Eds.). Women's Health (1st ed., pp. 422-429). Istanbul: Kenan Offset Printing.

Bilge A, Unal G (2005). Anger and anxiety levels in patients with cancer of the determination. Ege University School of Nursing Journal, 21, 37-46.

Brabin L, Roberts SA, Farzaneh F, Kitchener HC (2006). Future 


\section{Cansu Gunaydın and Nuran Gencturk}

acceptance of adolescent human papillomavirus vaccination: A survey of parental attitudes. Br J Cancer, 24, 3087-94.

Dinh TA, Rosenthal SL, Doan ED, et al (2007). Attidues of mothers in Da Nang, Vietnam toward a human papillomavirus vaccine. $J$ Adolescent Health, 40, 559-63.

Dozier KJ, Lawrence D (2000). Socio-demographicpredictors of adherence to annual cervical cancer screening in minority women. Cancer Nursing, 23, 350-6.

Ertem G (2009). Awareness of cervical cancer risk factors and screening behaviour among nurses in a rural region of Turkey. Asian Pac J Cancer Prev, 10, 735-8.

Giles M, Garland S (2006). A study of women's knowledge regarding human papilloma virus infection, cervical cancer and human papilloma virus vaccines, Aust NZ J Obstets Gynaecol, 46, 311-5.

Gokaslan H and Uyar EE (2004). Cervical cancer screening with the pap smear. Turkish J Family Practice, 8, 105-10.

Gumus AB and Cam O (2011). Relationships between early diagnosis attitudes in cervical cancer of women and levels of self-esteem, body perception and hopelessness. Medicus Nobel, 7, 46-52.

Hacimustafaoglu M (2011). Routine immunisation schedules of Turkey; extended immunisation schedule. J Pediatric Infectious, 5, 244-51.

International Agency for Research on Cancer (2012). Cervical cancer estimated incidence mortality and prevalence worldwide in 2012 at: http://globocan.iarc.fr/old/FactSheets/ cancers/cervix-new.asp

Isik Andsoy I, Gul A (2014). Breast, cervix and colorectal cancer knowledge among nurses in Turkey. Asian Pac J Cancer Prev, 15, 2267-72.

Kose MF (2006). Cervical intraepithelial diseases. In N. Cicek, C. Akyurek, C Celik, A Haberal (Eds.). Obstetrics and Accurate Information (pp. 98, 1153-1446). Istanbul: Gunes Bookshop Ltd.Std.

Lenehan JG, Leonard KC, Nandra S, et al (2008). Women's knowledge, attitudes and intentions concerning human papillomavirus vaccination: findings of a waiting room survey of obstetrics-gynaecology outpatients. J Obsts Gynaecol Can, 30, 489-99.

Moraros J, Bird Y, Barney DD, et al (2006). A pilot study: HPV infection knowledge and HPV vaccine acceptance among women residing in ciudad juarez, Mexico. Californian $J$ Health Promotion, 4, 177-86.

Numanoglu C (2010). Preinvasive lesions of the lower genital tract. In Ceylan Y, Yıldırım G, Aslan, H, Gul A, Gedikbası A (Eds.), Williams Gynecology (pp. 29, 622-625). Istanbul: Medical Nobel Bookstores.

Ozan H (2005). PAP Smear: When? How? Who? Turkey J Gynecol Obstetrics, 2, 35-40.

Ozan YD and Ertem M (2011). In Diyarbakir, the frequency of cervical cancer screening in different occupational groups and knowledge; 2007. Turkish J Family Practice, 15, 147-52.

Ozdemir O, Bilgili N (2010). Knowledge and practices of nurses working in an education hospital on early diagnosis of breast and cervix cancers. Prev Medicine Bull, 9, 605-12.

Saraiya UB (2003). Preventable but not prevented: the reality of cervical cancer. JObstetrican Gynecology, 29, 351-9.

Saslow D, Runowicz CD, Solomon D (2002). American Cancer Society guideline for the early detection of cervical neoplasia and cancer. CA A Cancer J Clin, 52, 342-62.

Sirovich BE and Welch HG (2004). Cervical cancer screening among women without a cervix. J Am Med Assoc, 291, 2990-3.

Waxman AG (2005). Guidelines for cervical cancer screening, history and scientific rationale. Clin Obstet Gynecol, 48, 77-97.
World Health Organization. (2008). Globocan 2008, Fast Stats, Less Developed Regions; Men, Women, Both Sexes, Summary Statistics (Access Date: 01.03.2012). http://globocan.iarc.fr/factsheets/populations/factsheet. asp?uno=902\#WOMEN

Yildirim JG and Arabaci Z (2014). Innovations in HPV vaccination and roles of nurses in cervical cancer prevention. Asian Pac J Cancer Prev, 15, 10053-6. 